\title{
Isolation, pure culture and characterization of Serratia symbiotica sp. nov., the R-type of secondary endosymbiont of the black bean aphid Aphis fabae
}

\author{
Correspondence \\ Ahmed Sabri \\ a.sabri@ulg.ac.be \\ Philippe Thonart \\ p.thonart@ulg.ac.be
}

\author{
Ahmed Sabri, ${ }^{1}$ Pascal Leroy, ${ }^{2}$ Eric Haubruge, ${ }^{2}$ Thierry Hance, ${ }^{3}$ \\ Isabelle Frère, ${ }^{3}$ Jacqueline Destain $^{1}$ and Philippe Thonart ${ }^{1}$ \\ ${ }^{1} \mathrm{CWBI}$, University of Liege B40, 4000 Liege, Belgium \\ ${ }^{2}$ Department of Functional and Evolutionary Entomology, Gembloux Agro-Bio Tech, 5030 \\ Gembloux, Belgium \\ ${ }^{3}$ Unité d'Ecologie et de Biogéographie, 1348 Louvain-la-Neuve, Belgium
}

\begin{abstract}
An intracellular symbiotic bacterium was isolated from the flora of a natural clone of the black bean aphid Aphis fabae. The strain was able to grow freely in aerobic conditions on a rich medium containing $1 \%$ of each of the following substrates: glucose, yeast extract and casein peptone. Pure culture was achieved through the use of solid-phase culture on the same medium and the strain was designated $\mathrm{CWBI}-2 \cdot 3^{\top}$. 16S rRNA gene sequence analysis revealed that strain CWBI$2.3^{\top}$ was a member of the class Gammaproteobacteria, having high sequence similarity ( $\left.>99 \%\right)$ with 'Candidatus Serratia symbiotica', the R-type of secondary endosymbiont that is found in several aphid species. As strain CWBI-2.3 $3^{\top}$ (=LMG $25624^{\top}=$ DSM $23270^{\top}$ ) was the first R-type symbiont to be isolated and characterized, it was designated as the type strain of Serratia symbiotica sp. nov.
\end{abstract}

Symbiosis is a common feature in insects, especially in insects feeding on exclusive and unbalanced diets (Buchner, 1965). For aphids, an association with an endosymbiotic bacterium Buchnera aphidicola combats the lack of essential amino acids in the phloem sap. In addition to this obligate symbiont, many aphids harbour facultative endosymbionts that enable them to expand their ecological niches and also help to provide protection against microbial and parasitoid attacks (Oliver et al., 2003; Tsuchida et al., 2004; Scarborough et al., 2005). Both primary and secondary symbionts are maternally inherited over aphid generations and can reside intracellularly in specialized cells and organs (Buchner, 1965; Baumann et al., 2000).

As they live in a nutrient-rich environment, many endosymbionts have relatively inactive biochemical profiles compared with those of their free-living relatives (Hypša \& Dale, 1997; Dale \& Maudlin, 1999; Pontes \& Dale, 2006). Consequently, most of them are difficult to isolate using conventional in vitro culture conditions and their phenotypic and genetic characterization is mostly incomplete (Hypša \& Dale, 1997; Darby et al., 2005). To date, only a few of these symbionts have been successfully characterized and currently a trivial nomenclature system is in use to

The GenBank/EMBL/DDBJ accession number for the 16S rRNA gene sequence of strain CWBI-2.3 ${ }^{\top}$ is GU394001. allow their distinction and classification (Gherna et al., 1991; Hypša \& Dale, 1997; Dale \& Maudlin, 1999).

'Candidatus Serratia symbiotica' is currently described as an endosymbiont from multiple aphid families. Recent studies have demonstrated that it plays different roles in the heat tolerance of the host and in their protection against parasitoids (Chen et al., 2000; Montllor et al., 2002; Oliver et al., 2003; Burke et al., 2010). In the aphid subgenus Cinara, 'Ca. S. symbiotica' has a long-term relationship with its hosts and appears to be in a transition phase from a facultative to an obligate symbiont for host survival and reproduction (Gil et al., 2002; Gómez-Valero et al., 2004; Pérez-Brocal et al., 2006; Lamelas et al., 2008; Burke et al., 2009).

In this study, the first isolation and in vitro culture of an endosymbiotic strain of ' $\mathrm{Ca}$. S. symbiotica' from the flora of a natural clone of the aphid Aphis fabae is described. This strain is proposed as the type strain of the secondary endosymbiont Serratia symbiotica sp. nov.

The novel strain, designated CWBI-2.3 ${ }^{\mathrm{T}}$, was isolated during the characterization of the microbiota of several laboratory and natural aphids collected in Belgium. The strain was among the flora of the natural clone of the black bean aphid Aphis fabae collected over a period corresponding to the first parthenogenetic generations (May 2009). 
For strain isolation, 40 specimens were surface-sterilized and extracted with 863 medium containing $\left(l^{-1}\right.$ distilled water) $10 \mathrm{~g}$ each of glucose, yeast extract and casein peptone. The extract was then plated on 868 agar medium (corresponding to 863 medium with $1.7 \%$ agar). Colonies of strain CWBI-2.3 $3^{\mathrm{T}}$ were visible after 2 weeks of incubation at $20{ }^{\circ} \mathrm{C}$ and the prevalence was about $10^{3}$ c.f.u. $\mathrm{mg}^{-1}$. The flora of the collected A. fabae clone contained two other bacteria identified as Acinetobacter calcoaceticus $\left(1.3 \times 10^{3}\right.$ c.f.u. $\left.\mathrm{mg}^{-1}\right)$ and Pseudomonas viridiflava $\left(0.7 \times 10^{3}\right.$ c.f.u. $\left.\mathrm{mg}^{-1}\right)$.

Colonies of strain CWBI- $2.3^{\mathrm{T}}$ were circular, uniform in size with entire edges, not pigmented and appeared off-white, smooth and shiny. Morphological features were examined by light microscopy and transmission electron microscopy (100-SX; JEOL) (Fig. 1). The strain was motile, rod-like $(0.5 \times 0.8-1.3 \mu \mathrm{m})$ and appeared mainly as single cells or in pairs.

The novel strain was maintained in the laboratory for several months and used for all of the subsequent experiments described in this study. Long-term preservation was possible by freezing at $-80{ }^{\circ} \mathrm{C}$ in culture medium with $20 \%$ (w/v) glycerol.

For strain identification, genomic DNA was extracted from cells grown at $20{ }^{\circ} \mathrm{C}$ for $120 \mathrm{~h}$ in 868 medium and purified by using a Wizard Genomic DNA purification kit (Promega). The primers used for PCR amplification of the $16 \mathrm{~S}$ rRNA gene were the universal primers 16SP0

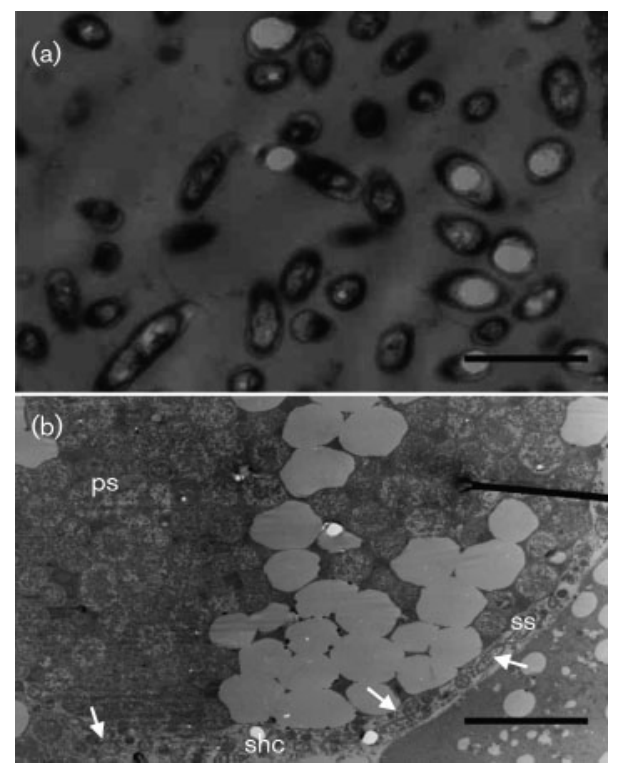

Fig. 1. (a) Transmission electron micrograph (TEM) of cells of strain $\mathrm{CWBI}-2.3^{\top}$ after incubation for 7 days on 868 agar medium. (b) TEM of a thin section of Aphis fabae showing the secondary symbiont (arrows) located in the bacteriosome in the cytoplasm of sheath cell (shc), (ss) secondary symbionts, (ps) primary symbionts. Bars, $1 \mu \mathrm{m}$ (a); $5 \mu \mathrm{m}$ (b).
GAAGAGTTTGATCCTGGCTCAG and 16SP6 CTACGGCTACCTTGTTACGA (Ventura et al., 2001). The PCR product was purified using GFX PCR DNA and a Gel Band kit (GE Healthcare). Sequencing was achieved using a Big Dye v.3.1 kit and a 3730 DNA Analyzer (Applied Biosystems). The primers used for sequencing were $\mathrm{F} 1$ (CTGGCTCAGGAYGAACG), F2 (GAGGCAGCAGTRGGGAAT), F3 (ACACCARTGGCGAAGGC) and F4 (GCACAAGCGGYGGAGCAT) for the coding DNA segment, and R1 (CTGCTGGCACGTAGTTAG), R2 (AATCCTGTTYGCTMCCCA), R3 (CCAACATCTCACGACACG) and R4 (TGTGTAGCCCWGGTCRTAAG) for the non-coding DNA segment. The sequences obtained (400-600 bp) were then assembled by using the BioEdit program. The resulting sequence $(1478 \mathrm{bp})$ of strain CWBI- $2.3^{\mathrm{T}}$ was deposited in GenBank database with the accession number GU394001. The sequence of strain CWBI-2.3 ${ }^{\mathrm{T}}$ was compared with other sequences in GenBank by using the BLASTN program (Altschul et al., 1997).

The 16S rRNA gene sequence of the novel strain shared $99.9 \%$ similarity with that of ' $\mathrm{Ca}$. Serratia symbiotica' strains found in Aphis craccivora (1463/1464 bp) (Tsuchida et al., 2006). It was also closely related to ' $\mathrm{Ca}$. Serratia symbiotica' strains found in Acyrthosiphon pisum (99.7\%) and Cinara cupressi (99.6\%) (Unterman et al., 1989; Fukatsu et al., 2000; Tsuchida et al., 2006; Lamelas et al., 2008; Burke et al., 2009).

A comparison with 16S rRNA gene sequences of the type strains of free-living members of the genus Serratia showed that strain CWBI-2.3 ${ }^{\mathrm{T}}$ shared $97.7 \%$ similarity with Serratia ficaria, $97.5 \%$ with Serratia entomophila, $97.4 \%$ with Serratia plymuthica, $97.1 \%$ with Serratia proteamaculans, $97.0 \%$ with Serratia grimesii, $96.9 \%$ with Serratia nematodiphila, $96.8 \%$ with Serratia odorifera, $96.7 \%$ with Serratia marcescens, 96.4\% with Serratia fonticola, 96\% with Serratia ureilytica, $96 \%$ with Serratia glossinae and $95.6 \%$ with Serratia rubidaea.

Phylogenetic analysis was conducted by using MEGA 4.0 software (Tamura et al., 2007). Sequence similarity was estimated using the likelihood method and phylogenetic trees were constructed with the neighbour-joining method (Saitou \& Nei, 1987). Bootstrap analysis (1000 resamplings) was used to evaluate the topology of the trees (Felsenstein, 1985).

Recent phylogenetic reconstructions of lineages of symbiotic members of the genus Serratia have revealed the existence of two groups of ' $\mathrm{Ca}$. S. symbiotica' in aphids (Lamelas et al., 2008; Burke et al., 2009). The first (cluster A) encompasses S-symbionts belonging to different subfamilies of the family Aphididae; Aphidinae, Chaitophorinae, Eriomatinae and some members of the subfamily Lachninae. The second (cluster B) comprises only endosymbionts of the genus Serratia from the subfamily Lachninae which are considered to be primary-type endosymbionts (Lamelas et al., 2008). The phylogenetic tree (Fig. 2) showed that 


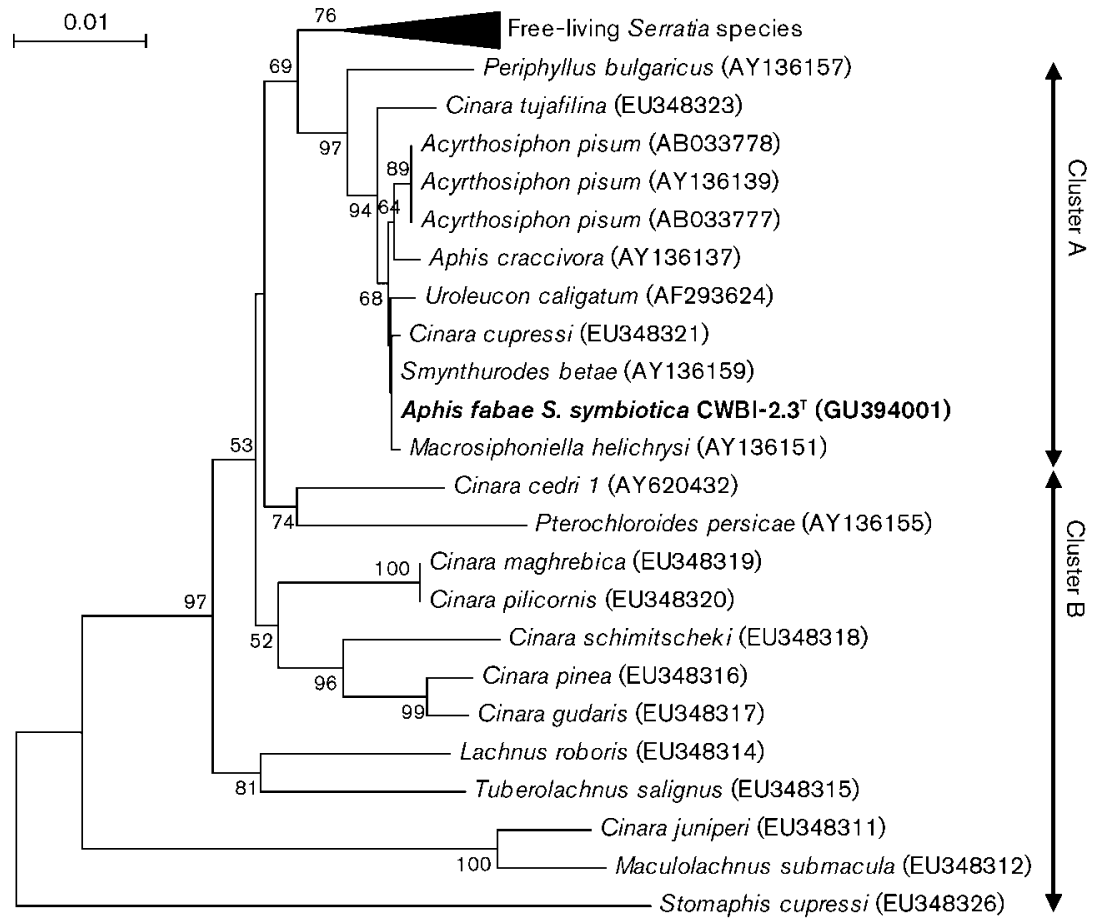

Fig. 2. Phylogenetic position of strain CWBI$2.3^{\top}$ among 'Ca. S. symbiotica' strains of aphids. The evolutionary history was inferred using the neighbour-joining tree based on analysis of $16 \mathrm{~S}$ rRNA gene sequence data. Endosymbionts are referenced by their aphid host taxa and by the GenBank accession numbers for their 16S rRNA gene sequences. Bootstrap values $>50 \%$ (expressed as percentages of 1000 replications) are shown at branch points. Bar, 0.01 substitutions per nucleotide position. strain CWBI- $2.3^{\mathrm{T}}$ belonged to cluster A of the S-symbiont lineages.

For free-living species of the genus Serratia, phylogenetic affinities revealed two clusters. The first cluster (cluster II) included S. marcescens, S. rubidaea, S. liquefaciens, S. ureilytica, S. nematodiphila and $S$. odorifera. The second cluster (cluster I) included S. proteamaculans, S. grimesii, $S$. plymuthica, S. fonticola, S. entomophila and S. ficaria. Strain CWBI- $2.3^{\mathrm{T}}$ clearly belonged to the second cluster (cluster I, Fig. 3).

DNA-DNA hybridizations were performed with strain CWBI- $2.3^{\mathrm{T}}$ and the three most closely related species in the second cluster (cluster I); S. ficaria, S. entomophila and S. plymuthica. The analysis was performed fluorometrically according to the method of Ezaki et al. (1989) using photobiotin-labelled DNA probes and microdilution wells. Strain CWBI-2.3 ${ }^{\mathrm{T}}$ showed DNA-DNA relatedness values of $23 \%, 22 \%$ and $21 \%$ with S. ficaria, S. entomophila and S. plymuthica, respectively. This indicated that the secondary symbiont of the aphid, strain CWBI- $2.3^{\mathrm{T}}$, represented a distinct species of the genus Serratia according to the criteria used for the delineation of bacterial species (Wayne et al., 1987).

For DNA G $+\mathrm{C}$ analysis, genomic DNA was extracted and purified according to Gevers et al. (2001) and the G+C content was determined by HPLC (Mesbah et al., 1989). The DNA G $+\mathrm{C}$ content of CWBI-2.3 ${ }^{\mathrm{T}}$ strain was $52.7 \mathrm{~mol} \%$ and was similar to that found for S. liquefaciens $(51.9 \mathrm{~mol} \%)$ and S. fonticola $(51.5 \mathrm{~mol} \%)$, but was less than that determined for most free-living species of the genus Serratia (Grimont et al., 1982; Gavini et al., 1979).
Genome size reduction and a low $\mathrm{G}+\mathrm{C}$ content of the genomic DNA are common characteristics of endosymbiotic bacteria (Moran et al., 2008). The G $+\mathrm{C}$ content of the strain CWBI- $2.3^{\mathrm{T}}$ was relatively low when compared with that of many free-living species of the genus Serratia; however, it was much higher than that reported for several other insect endosymbionts, in which the DNA G+C content is often below $33 \mathrm{~mol} \%$ (Moran et al., 2008).

The novel strain was able to grow aerobically and microaerobically at $0-4 \%(\mathrm{w} / \mathrm{v}) \mathrm{NaCl}$ and at $10-30{ }^{\circ} \mathrm{C}$, with an optimum growth temperature of $25{ }^{\circ} \mathrm{C}$. In an attempt to define a minimal medium for the growth of the novel strain, it was found that the strain was unable to grow on a mineral medium (MM) [0.2\% $\left(\mathrm{NH}_{4}\right)_{2} \mathrm{SO}_{4} ; 0.2 \%$ $\mathrm{Na}_{2} \mathrm{SO}_{4} ; \quad 1.5 \% \quad \mathrm{~K}_{2} \mathrm{HPO}_{4} ; \quad 0.05 \% \quad \mathrm{KH}_{2} \mathrm{PO}_{4} ; \quad 0.01 \%$ $\mathrm{MgSO}_{4} \cdot 7 \mathrm{H}_{2} \mathrm{O}$ and $0.003 \% \mathrm{CaCl}_{2}$ ] containing glucose $(1 \%)$ and the 20 amino acids $(0.01 \%$ each $)\left(\mathrm{OD}_{600}>0.1\right)$. However, it was able to grow on MM containing $1 \%$ glucose and $1 \%$ casein peptone instead of pure amino acids $\left(\mathrm{OD}_{600}=0.6\right)$. Weak growth was obtained on MM containing only casein peptone $(1 \%)\left(\mathrm{OD}_{600}=0.2\right)$. On 863 medium (containing $1 \%$ each of glucose, casein peptone and yeast extract), growth reached an $\mathrm{OD}_{600}$ of 1.4.

For the assimilation and acidification tests, API 20E, API $20 \mathrm{NE}$ and API $50 \mathrm{CH}$ strips (bioMérieux) were used and the incubation times were about 2 weeks for strain CWBI$2.3^{\mathrm{T}}$ and $24 \mathrm{~h}$ for the free-living Serratia strains. For the assimilation tests (API 20NE strips), the novel strain gave a positive result only for the assimilation of glucose and $\mathrm{N}$ acetylglucosamine as a carbon source. However, the novel strain was unable to grow on arabinose, mannose, 


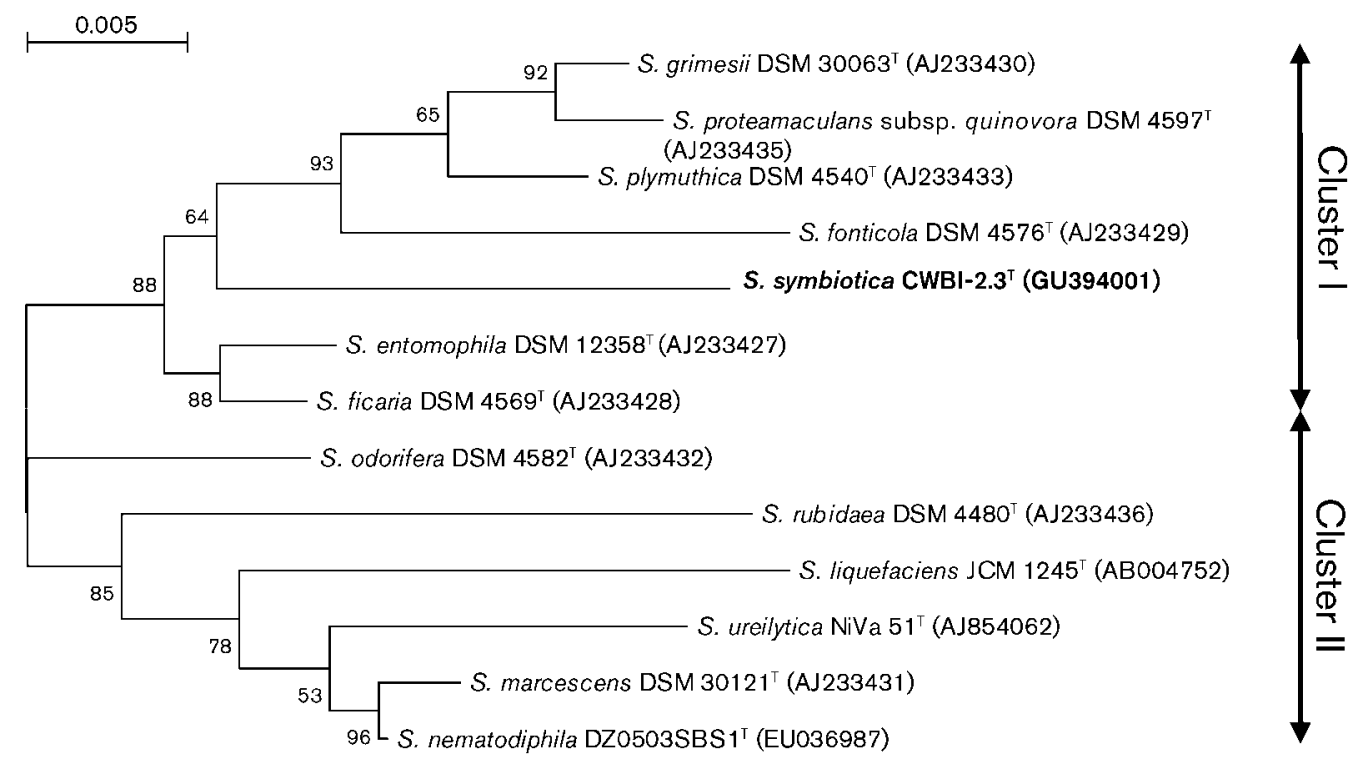

Fig. 3. Phylogenetic position of strain $\mathrm{CWBI}-2 \cdot 3^{\top}$ among related free-living species of the genus. The tree was generated using the neighbour-joining method and based on 16S rRNA gene sequence data analysis. Species are referenced by strain numbers and GenBank accession numbers for their 16S rRNA sequences. Bootstrap values are expressed as percentages of 1000 replications and are shown at branch points. Bar, 0.005 substitutions per nucleotide position.

mannitol, maltose, gluconate, caprate, adipate, malate, citrate or phenylacetate. In acidification tests (API 50CH strips), strain CWBI- $2.3^{\mathrm{T}}$ was weakly positive for acid production from glucose, sucrose and aesculin, but was unable to produce acid from the 46 remaining carbohydrates present on the strips (Table 1). With the API 20E strips, strain CWBI- $2.3^{\mathrm{T}}$ was positive for the VogesProskauer reaction but gave a negative result for $\beta$ galactosidase, arginine dihydrolase, lysine decarboxylase, ornithine decarboxylase, urease, tryptophan deaminase and gelatinase. The novel strain was also unable to reduce nitrate or produce $\mathrm{H}_{2} \mathrm{~S}$ or indole. The strain was also negative in tests for DNase, lipase (Tween 80), lecithinase, chitinase and in the methyl red test.

Phenotypic characterization revealed that strain CWBI$2.3^{\mathrm{T}}$ was characterized by a highly restricted metabolic profile in comparison with the free-living members of the genus Serratia (Grimont et al., 1988; Ajithkumar et al., 2003; Bhadra et al., 2005; Zhang et al., 2009; Geiger et al., 2010). Indeed, in general, members of the genus Serratia are able to produce a wide range of hydrolases and to develop on many carbon sources. They are usually distinguished from other members of the family Enterobacteriaceae by their growth on mineral medium without growth factors, as well as by their acid production from maltose, mannitol and trehalose and by their ability to produce DNase, lipase, and gelatinase (Farmer et al., 1985). It appears that strain CWBI- $2.3^{\mathrm{T}}$ has lost all these characteristics during its adaptation to its symbiotic life. In the genus Serratia, this kind of adaptation, with loss of metabolic diversity, has been previously reported for the biogroup 1 of $S$. marcescens. The latter has lost some of its metabolic activities through the natural selection of strains adapted to the human urinary tract (Farmer et al., 1985). For mutualistic intracellular bacteria in general, the loss of metabolic and genetic diversity is usually a consequence of evolution in a closed environment in which many molecules can be obtained from the host (Andersson \& Kurland, 1998; Dale \& Maudlin, 1999; Moran \& Wernegreen, 2000; Dale \& Moran, 2006). This loss of metabolic and genetic diversity is probably the main reason why many insect endosymbionts are difficult to isolate and characterize.

For quantitative analysis of the cellular fatty acid composition, cells were grown aerobically for $24 \mathrm{~h}$ at $28{ }^{\circ} \mathrm{C}$ on TSA medium (BBL 11768). Inoculation and harvesting of cells were performed as described by the Microbial Identification System, Inc. (MIDI). The extraction and analysis were performed as prescribed by the MIDI system and the whole-cell fatty acid composition was determined using GC.

The fatty acid profile of strain CWBI- $2.3^{\mathrm{T}}$ was compared with those of some related free-living species of the genus Serratia (Table 2). Summed features 2 and 3 (comprising $\mathrm{C}_{12: 0}$ alde, an unknown fatty acid with equivalent length 10.928 and $\mathrm{C}_{14: 0} 3-\mathrm{OH} / \mathrm{C}_{16: 1}$ iso $\mathrm{I}$, and $\mathrm{C}_{16: 1} \omega 7 c /$ iso $\mathrm{C}_{15: 0}$ $2-\mathrm{OH}$, respectively) were also among the predominant fatty acids of most of the strains, except for $S$. nematodiphila, in which summed feature 3 was present only in trace amounts but the amount of $\mathrm{C}_{19: 0}$ cyclo $\omega 7 c$ was particularly high. The most marked differences between strain CWBI-2.3 ${ }^{\mathrm{T}}$ 
Table 1. Biochemical and physiological characteristics of strain $\mathrm{CWBI}-2.3^{\top}$ compared with the most closely related type strains of free-living taxa

Taxa: 1 , strain CWBI-2.3 ${ }^{\mathrm{T}} ; 2$, S. ficaria LMG $7881^{\mathrm{T}} ; 3$, S. entomophila LMG $8456^{\mathrm{T}} ; 4$, S. plymuthica LMG $7886^{\mathrm{T}} ; 5$, S. grimesii LMG $7883^{\mathrm{T}} ; 6$, S. proteomaculans LMG $7887^{\mathrm{T}}$. All strains were rod-shaped, motile and non-spore-forming. All strains were negative for indole and $\mathrm{H}_{2} \mathrm{~S}$ production and for tryptophan deaminase, oxidase and urease. All strains assimilated $\mathrm{N}$-acetylglucosamine. All strains were unable to grow on adipate and phenylacetate. All strains were able to produce acid from $\mathrm{N}$-acetylglucosamine, aesculin, D-fructose, D-glucose and sucrose. All strains were unable to produce acid from erythritol, Darabinose, L-xylose, D-adonitol, methyl $\beta$-D-xylopyranoside, L-sorbose, L-rhamnose, dulcitol, methyl $\alpha$-D-mannopyranoside, methyl $\alpha$-D-glucopyranoside, inulin, glycogen, xylitol, D-lyxose, D-tagatose, D-fucose, L-fucose or L-arabitol.

\begin{tabular}{|c|c|c|c|c|c|c|}
\hline Characteristic & 1 & 2 & 3 & 4 & 5 & 6 \\
\hline Pigment production & - & - & - & + & - & - \\
\hline$\beta$-Galactosidase & - & + & + & + & + & + \\
\hline Arginine dihydrolase & - & + & - & + & + & - \\
\hline Lysine decarboxylase & - & - & - & - & + & + \\
\hline Ornithine decarboxylase & - & - & - & - & + & + \\
\hline Gelatinase & - & + & + & + & + & + \\
\hline Voges-Proskauer reaction & + & + & + & + & + & + \\
\hline Methyl red test & - & - & - & + & + & + \\
\hline DNase & - & + & + & + & + & + \\
\hline Lipase (Tween 80) & - & + & + & + & + & + \\
\hline Lecithinase & - & + & + & + & + & + \\
\hline Chitinase & - & + & + & + & + & + \\
\hline Caseinase & - & - & + & + & - & - \\
\hline Catalase & + & + & + & + & + & + \\
\hline Aesculin hydrolysis & + & + & + & + & + & + \\
\hline Growth temperature $\left({ }^{\circ} \mathrm{C}\right)$ & $10-30$ & $5-37$ & $5-40$ & $5-37$ & $5-37$ & $5-37$ \\
\hline $\mathrm{NaCl}(\% \mathrm{w} / \mathrm{v})$ & $0-4$ & $0-8$ & $0-8$ & $0-8$ & $0-8$ & $0-8$ \\
\hline $\begin{array}{l}\text { DNA G + C content } \\
(\mathrm{mol} \%)\end{array}$ & 52.7 & 59.6 & 58 & ND & $\mathrm{ND}$ & ND \\
\hline \multicolumn{7}{|l|}{ Carbohydrate assimilation } \\
\hline Caprate & - & + & - & - & + & + \\
\hline Citrate & - & + & + & + & - & + \\
\hline Gluconate & - & + & + & + & + & + \\
\hline Glycerol & - & - & + & - & + & + \\
\hline Malate & - & + & + & + & + & + \\
\hline Maltose & - & + & + & + & + & + \\
\hline Mannitol & - & + & + & + & + & + \\
\hline Mannose & - & + & + & + & + & + \\
\hline \multicolumn{7}{|l|}{ Acid production } \\
\hline Amygdalin & - & + & + & + & + & + \\
\hline L-Arabinose & - & + & - & + & + & + \\
\hline D-Arabitol & - & + & + & - & - & - \\
\hline Arbutin & - & - & + & + & + & + \\
\hline D-Cellobiose & - & + & - & + & + & - \\
\hline D-Galactose & - & + & + & + & + & + \\
\hline Gentiobiose & - & + & + & - & + & + \\
\hline Inositol & - & + & + & + & + & + \\
\hline Lactose & - & - & - & + & - & - \\
\hline Maltose & - & + & + & + & + & + \\
\hline D-Mannitol & - & + & + & + & + & + \\
\hline
\end{tabular}

Table 1. cont

\begin{tabular}{|lcccccc|}
\hline Characteristic & $\mathbf{1}$ & $\mathbf{2}$ & $\mathbf{3}$ & $\mathbf{4}$ & $\mathbf{5}$ & $\mathbf{6}$ \\
\hline D-Mannose & - & + & + & + & + & + \\
Melezitose & - & + & - & + & + & - \\
Melibiose & - & + & + & + & + & + \\
Potassium & - & + & + & + & + & + \\
2-ketogluconate & & & & & & \\
Potassium & - & + & + & + & + & + \\
5-ketogluconate & & & & & & \\
Potassium gluconate & - & + & + & + & + & + \\
Raffinose & - & + & - & + & - & - \\
Ribose & - & + & + & + & + & + \\
Salicin & - & + & + & + & + & + \\
Sorbitol & - & + & - & + & + & - \\
D-Sorbitol & - & + & - & + & + & - \\
Starch & - & - & - & - & + & - \\
Trehalose & - & + & + & + & + & + \\
Turanose & - & + & - & + & + & + \\
D-Xylose & - & + & - & + & + & + \\
\hline
\end{tabular}

and the free-living strains tested concerned the fatty acid $\mathrm{C}_{17: 0}$ cyclo, which was absent from strain CWBI-2.3 ${ }^{\mathrm{T}}$ and present in large amounts in most tested strains. The content of summed feature 3 was particularly high in strain CWBI- $2.3^{\mathrm{T}}$ when compared with the level in the other species tested. Such differences confirmed that strain CWBI- $2.3^{\mathrm{T}}$ represented a distinct and separate species within the genus Serratia.

Strain CWBI- $2.3^{\mathrm{T}}$ was highly sensitive to rifampicin, tetracycline and chloramphenicol $\left(<10 \mu \mathrm{g} \mathrm{ml}^{-1}\right)$. It was sensitive to streptomycin $\left(10 \mu \mathrm{g} \mathrm{ml}^{-1}\right)$, kanamycin $\left(20 \mu \mathrm{g} \mathrm{ml}^{-1}\right)$, ampicillin $\left(20 \mu \mathrm{g} \mathrm{ml}^{-1}\right)$, erythromycin $\left(30 \mu \mathrm{g} \mathrm{ml}^{-1}\right)$ and gentamicin $\left(40 \mu \mathrm{g} \mathrm{ml}^{-1}\right)$, but resistant to vancomycin.

Due to their inability to grow axenically, no strain of ' $\mathrm{Ca}$. S. symbiotica' has been isolated and characterized previously, as required for formal description of the species. Consequently, the taxon has previously been named under the Candidatus provision for the informal naming of uncultured representatives of new genera and species (Moran et al., 2005). As strain CWBI-2.3 ${ }^{\mathrm{T}}$ is the first strain of ' $\mathrm{Ca}$. S. symbiotica' to be purified and characterized, it is designated as the type strain of Serratia symbiotica sp. nov.

The availability of a pure culture of $S$. symbiotica sp. nov. will provide valuable opportunities to promote the position of the species in the genus Serratia. The provisional name 'Candidatus Serratia symbiotica' has been assigned to many strains residing in several aphid species mainly on the basis of morphological observations and $16 \mathrm{~S}$ rRNA gene sequence similarities. Even though the 16S rRNA gene sequences of strains of ' $\mathrm{Ca}$. S. symbiotica' have shown very high similarities, they may actually belong to separate species and so warrant further investigation. The isolation of strain CWBI- $2.3^{\mathrm{T}}$ should also stimulate further studies on the role of this species in aphids. 
Table 2. Cellular fatty acid compositions of strain CWBI- $2.3^{\top}$ and the type strains of some related free-living members of the genus Serratia

Taxa: 1, strain CWB1-2.3 ${ }^{\mathrm{T}} ; 2$, S. ficaria LMG $7881^{\mathrm{T}}$; 3. S. entomophila LMG $8456^{\mathrm{T}}$; 4, S. plymuthica LMG $7886^{\mathrm{T}}$; 5, S. nematodiphila DZ0503SBS1 $^{\mathrm{T}}$ (data from Zhang et al., 2009); 6, S. odorifera LMG $7885^{\mathrm{T}}$ (data from the Sherlock MIS TSBA50 identification library); 7, S. marcescens DSM $30121^{\mathrm{T}}$. $\operatorname{tr}$, Trace amount $(<1.0 \%)$; - , not detected; ND, not determined.

\begin{tabular}{|c|c|c|c|c|c|c|c|}
\hline Fatty acid & 1 & 2 & 3 & 4 & 5 & 6 & 7 \\
\hline $\mathrm{C}_{10: 0}$ & $\operatorname{tr}$ & $\operatorname{tr}$ & - & - & - & - & - \\
\hline $\mathrm{C}_{10: 0} 3-\mathrm{OH}$ & - & - & - & - & $\operatorname{tr}$ & - & - \\
\hline $\mathrm{C}_{11: 0}$ & - & $\operatorname{tr}$ & - & - & - & - & - \\
\hline $\mathrm{C}_{12: 0}$ & 3.74 & 5.80 & 4.73 & 4.93 & 2.47 & 2.95 & 1.46 \\
\hline $\mathrm{C}_{13: 0}$ & - & $\operatorname{tr}$ & $\operatorname{tr}$ & - & - & - & - \\
\hline $\mathrm{C}_{12: 0} 2-\mathrm{OH}$ & - & 1.51 & $\operatorname{tr}$ & - & $\operatorname{tr}$ & $\operatorname{tr}$ & $\operatorname{tr}$ \\
\hline $\mathrm{C}_{12: 0} 3-\mathrm{OH}$ & - & - & - & - & $\operatorname{tr}$ & - & - \\
\hline $\mathrm{C}_{14: 0}$ & 8.87 & 8.14 & 6.44 & 7.60 & 8.40 & 7.40 & 6.94 \\
\hline $\mathrm{C}_{14: 0} 2-\mathrm{OH}$ & - & - & 2.38 & - & 1.02 & - & 2.05 \\
\hline $\mathrm{C}_{15: 0}$ & - & - & - & - & $\operatorname{tr}$ & - & - \\
\hline $\mathrm{C}_{15: 0}$ anteiso & $\operatorname{tr}$ & - & - & - & - & - & - \\
\hline $\mathrm{C}_{16: 0}$ & 29.86 & 24.51 & 24.47 & 31.48 & 34.76 & 30.74 & 31.86 \\
\hline $\mathrm{C}_{16: 1} \omega 5 c$ & $\operatorname{tr}$ & - & - & - & - & - & - \\
\hline $\mathrm{C}_{17: 0}$ cyclo & - & 12.45 & 10.86 & 8.71 & 20.03 & 4.96 & 11.68 \\
\hline $\mathrm{C}_{17: 0}$ & - & 2.26 & 1.85 & - & - & - & $\operatorname{tr}$ \\
\hline $\mathrm{C}_{18: 0}$ & - & $\operatorname{tr}$ & $\operatorname{tr}$ & 1.13 & $\operatorname{tr}$ & $\operatorname{tr}$ & $\operatorname{tr}$ \\
\hline $\mathrm{C}_{18: 1} \omega 7 c$ & 4.22 & 9.56 & 10.51 & 7.69 & 1.67 & 14.40 & 16.88 \\
\hline $\mathrm{C}_{19: 0}$ iso & - & - & - & - & $\operatorname{tr}$ & - & - \\
\hline $\mathrm{C}_{19: 0}$ cyclo $\omega 7 c$ & - & - & - & - & 17.24 & $\operatorname{tr}$ & 1.24 \\
\hline $\mathrm{C}_{19: 0}$ cyclo $\omega 8 \mathrm{c}$ & - & 1.68 & $\operatorname{tr}$ & - & - & - & - \\
\hline $\begin{array}{l}\text { Unknown } \mathrm{ECL}^{*} \\
14.502\end{array}$ & $\operatorname{tr}$ & - & - & $\operatorname{tr}$ & $\operatorname{tr}$ & $\operatorname{tr}$ & $\operatorname{tr}$ \\
\hline \multicolumn{8}{|l|}{ Summed features $\dagger$} \\
\hline 1 & - & $\operatorname{tr}$ & $\operatorname{tr}$ & - & - & - & - \\
\hline 2 & 12.20 & 14.53 & 15.14 & 13.94 & 7.56 & 8.98 & 8.44 \\
\hline 3 & 40.11 & 13.71 & 19.53 & 23.84 & $\operatorname{tr}$ & 28.04 & 16.51 \\
\hline
\end{tabular}

${ }^{\star}$ ECL, Equivalent chain-length.

$\dagger$ Summed features represent two or three fatty acids that cannot be separated by the Microbial Identification System. Summed feature 1 comprises $\mathrm{C}_{13: 0}$ 3-OH and/or iso- $\mathrm{C}_{15: 1} \mathrm{I} / \mathrm{H}$; summed feature 2 comprises $\mathrm{C}_{12: 0}$ alde, unknown ECL 10.928, iso- $\mathrm{C}_{16: 1}$ and $\mathrm{C}_{14: 0} 3$ $\mathrm{OH}$; summed feature 3 comprises iso- $\mathrm{C}_{15: 0} 2-\mathrm{OH}$ and/or $\mathrm{C}_{16: 1} \omega 7 c$.

The inactive biochemical profile of the novel species suggests that the loss of metabolic diversity could be gradual and it may be that phenotypic diversity may exist between strains of S. symbiotica. This diversity is probably a result of an overall evolution within the species which forms a continuum from partially free-living strains, such as strain CWBI- $2.3^{\mathrm{T}}$, to the highly host-dependent strain recently described in Cinara aphids (Pérez-Brocal et al., 2006).

\section{Description of Serratia symbiotica sp. nov.}

Serratia symbiotica [sym.bi.o'ti.ca. N.L. fem. adj. symbiotica (from Gr. n. sumbios a companion, partner) living together].
Cells are motile, Gram-negative-staining rods $(0.5 \times 0.8-$ $1.3 \mu \mathrm{m})$. Grows axenically on a rich medium containing glucose, casein peptone and yeast extract. Growth is optimal in aerobic conditions but growth also occurs in microaerobic conditions. On nutrient agar, colonies are circular, non-pigmented, off-white and smooth and shiny with entire margins. Cells grow at $10-30{ }^{\circ} \mathrm{C}$ (optimum, $25{ }^{\circ} \mathrm{C}$ ), $\mathrm{pH}$ 6-8 (optimum, 7) and with $0-4 \%(\mathrm{w} / \mathrm{v}) \mathrm{NaCl}$. Positive in tests for catalase and the Voges-Proskauer reaction. Negative result in tests for $\beta$-galactosidase, arginine dihydrolase, lysine decarboxylase, ornithine decarboxylase, gelatinase, DNase, lipase (Tween 80), lecithinase, chitinase, caseinase and for the methyl red test. Assimilation and acidification tests, performed on API 20NE and API 50CH strips, give a positive result for the assimilation of glucose and $\mathrm{N}$-acetylglucosamine. Weakly positive for acid production from glucose, sucrose and aesculin. Negative result for all remaining tests present on API $20 \mathrm{NE}$ and API 50CH strips. Whole-cell fatty acids are $\mathrm{C}_{10: 0}, \mathrm{C}_{12: 0}, \mathrm{C}_{14: 0}$, an unknown fatty acid with equivalent length 14.502, $\mathrm{C}_{15: 0}$ anteiso, $\mathrm{C}_{16: 1} \omega 5 c, \mathrm{C}_{16: 0}, \mathrm{C}_{18: 1} \omega 7 c$, summed feature 2 (comprising $\mathrm{C}_{12: 0}$ alde, unknown fatty acid with equivalent length 10.928 , and $\mathrm{C}_{14: 0} 3-\mathrm{OH} / \mathrm{C}_{16: 1}$ iso I) and summed feature 3 (comprising $\mathrm{C}_{16: 1} \omega 7 c / \mathrm{C}_{15}$ iso $2-\mathrm{OH}$ ).

The type strain is CWBI-2.3 $3^{\mathrm{T}} \quad\left(=\mathrm{LMG} 25624^{\mathrm{T}}=\mathrm{DSM}\right.$ $23270^{\mathrm{T}}$ ). The type strain is the R-type of the secondary endosymbiont associated symbiotically with a natural clone of Aphis fabae collected in Belgium. The bacterium lives in the host body and can be found in some host tissues and fluids, mostly in the bacteriosome in the cytoplasm of the sheath cells. The DNA G + C content of the type strain is $52.7 \mathrm{~mol} \%$.

\section{Acknowledgements}

This work was supported by 'la Région Wallonne de Belgique' convention Waleo2 no. 061/6288. We thank Dr V. Dhennin from the genotranscriptomics platform, GIGA, University of Liege (http:// www.giga.ulg.ac.be/) for $16 \mathrm{~S}$ rRNA gene sequencing. We are indebted to Dr S. Van Trappen from the BCCM/LMG Bacterial Collection for their support in the characterization of the strain.

\section{References}

Ajithkumar, B., Ajithkumar, V. P., Iriye, R., Doi, Y. \& Sakai, T. (2003). Spore-forming Serratia marcescens subsp. sakuensis subsp. nov., isolated from a domestic wastewater treatment tank. Int J Syst Evol Microbiol 53, 253-258.

Altschul, S. F., Madden, T. L., Schäffer, A. A., Zhang, J., Zhang, Z., Miller, W. \& Lipman, D. J. (1997). Gapped BLAST and PSI-BLAST: a new generation of protein database search programs. Nucleic Acids Res 25, 3389-3402.

Andersson, S. G. E. \& Kurland, C. G. (1998). Reductive evolution of resident genomes. Trends Microbiol 6, 263-268.

Baumann, P., Moran, N. \& Baumann, L. (2000). Bacteriocyteassociated endosymbionts of insects. In The Prokaryotes, a Handbook on the Biology of Bacteria: Ecophysiology, Isolation, Identification, Applications. Edited by M. Dworkin. New York: Springer-Verlag. 
Bhadra, B., Roy, P. \& Chakraborty, R. (2005). Serratia ureilytica sp. nov., a novel urea-utilizing species. Int J Syst Evol Microbiol 55, 2155-2158.

Buchner, P. (1965). Endosymbiosis of animals with plant microorganisms. Edited by J. W. Sons. New York: Interscience Publishers.

Burke, G. R., Normark, B. B., Favret, C. \& Moran, N. A. (2009). Evolution and diversity of facultative symbionts from the aphid subfamily Lachninae. Appl Environ Microbiol 75, 5328-5335.

Burke, G., Fiehn, O. \& Moran, N. (2010). Effects of facultative symbionts and heat stress on the metabolome of pea aphids. ISME J 4, 242-252.

Chen, D. Q., Montllor, C. B. \& Purcell, A. H. (2000). Fitness effects of two facultative endosymbiotic bacteria on the pea aphid, Acyrthosiphon pisum, and the blue alfalfa aphid, A. kondoi. Entomol Exp Appl 95, 315-323.

Dale, C. \& Maudlin, I. (1999). Sodalis gen. nov. and Sodalis glossinidius sp. nov., a microaerophilic secondary endosymbiont of the tsetse fly Glossina morsitans morsitans. Int J Syst Bacteriol 49, 267-275.

Dale, C. \& Moran, N. A. (2006). Molecular interactions between bacterial symbionts and their hosts. Cell 126, 453-465.

Darby, A. C., Chandler, S. M., Welburn, S. C. \& Douglas, A. E. (2005). Aphid-symbiotic bacteria cultured in insect cell lines. Appl Environ Microbiol 71, 4833-4839.

Ezaki, T., Hashimoto, Y. \& Yabuuchi, E. (1989). Fluorometric deoxyribonucleic acid-deoxyribonucleic acid hybridization in microdilution wells as an alternative to membrane filter hybridization in which radioisotopes are used to determine genetic relatedness among bacterial strains. Int J Syst Bacteriol 39, 224-229.

Farmer, J. J., III, Davis, B. R., Hickman-Brenner, F. W., McWhorter, A., Huntley-Carter, G. P., Asbury, M. A., Riddle, C., Wathen-Grady, H. G., Elias, C. \& other authors (1985). Biochemical identification of new species and biogroups of Enterobacteriaceae isolated from clinical specimens. J Clin Microbiol 21, 46-76.

Felsenstein, J. (1985). Confidence limits on phylogenies: An approach using the bootstrap. Evolution 39, 783-791.

Fukatsu, T., Nikoh, N., Kawai, R. \& Koga, R. (2000). The secondary endosymbiotic bacterium of the pea aphid Acyrthosiphon pisum (Insecta: homoptera). Appl Environ Microbiol 66, 2748-2758.

Gavini, F., Ferragut, C., Izard, D., Trinel, P. A., Leclerc, H., Lefebvre, B. \& Mossel, D. A. A. (1979). Serratia fonticola, a new species from water. Int J Syst Bacteriol 29, 92-101.

Geiger, A., Fardeau, M.-L., Falsen, E., Ollivier, B. \& Cuny, G. (2010). Serratia glossinae sp. nov., isolated from the midgut of the tsetse fly Glossina palpalis gambiensis. Int J Syst Evol Microbiol 60, 1261-1265.

Gevers, D., Huys, G. \& Swings, J. (2001). Applicability of rep-PCR fingerprinting for identification of Lactobacillus species. FEMS Microbiol Lett 205, 31-36.

Gherna, R. L., Werren, J. H., Weisburg, W., Cote, R., Woese, C. R., Mandelco, L. \& Brenner, D. J. (1991). Arsenophonus nasoniae gen. nov., sp. nov., the causative agent of the son-killer trait in the parasitic wasp Nasonia vitripennis. Int J Syst Bacteriol 41, 563-565.

Gil, R., Sabater-Muñoz, B., Latorre, A., Silva, F. J. \& Moya, A. (2002). Extreme genome reduction in Buchnera spp.: toward the minimal genome needed for symbiotic life. Proc Natl Acad Sci U S A 99, 44544458.

Gómez-Valero, L., Soriano-Navarro, M., Pérez-Brocal, V., Heddi, A., Moya, A., Garcia-Verdugo, J. M. \& Latorre, A. (2004). Coexistence of Wolbachia with Buchnera aphidicola and a secondary symbiont in the aphid Cinara cedri. J Bacteriol 186, 6626-6633.
Grimont, P. A. D., Grimont, F. \& Irino, K. (1982). Biochemical characterization of Serratia liquefaciens sensu stricto, Serratia proteamaculans, and Serratia grimesii sp. nov. Curr Microbiol 7, 69-74.

Grimont, P. A. D., Jackson, T. A., Ageron, E. \& Noonan, J. M. (1988). Serratia entomophila sp. nov. associated with amber disease in the New Zealand grass grub Costelytra zealandica. Int J Syst Bacteriol 38, $1-6$.

Hypša, V. \& Dale, C. (1997). In vitro culture and phylogenetic analysis of "Candidatus Arsenophonus triatominarum", an intracellular bacterium from the triatomine bug, Triatoma infestans. Int J Syst Bacteriol 47, 1140-1144.

Lamelas, A., Pérez-Brocal, V., Gómez-Valero, L., Gosalbes, M. J., Moya, A. \& Latorre, A. (2008). Evolution of the secondary symbiont "Candidatus Serratia symbiotica" in aphid species of the subfamily Lachninae. Appl Environ Microbiol 74, 4236-4240.

Mesbah, M., Premachandran, U. \& Whitman, W. B. (1989). Precise measurement of the $\mathrm{G}+\mathrm{C}$ content of deoxyribonucleic acid by highperformance liquid chromatography. Int J Syst Bacteriol 39, 159-167.

Montllor, C. B., Maxmen, A. \& Purcell, A. H. (2002). Facultative bacterial endosymbionts benefit pea aphids Acyrthosiphon pisum under heat stress. Ecol Entomol 27, 189-195.

Moran, N. A. \& Wernegreen, J. J. (2000). Lifestyle evolution in symbiotic bacteria: insights from genomics. Trends Ecol Evol 15, 321326.

Moran, N. A., Russell, J. A., Koga, R. \& Fukatsu, T. (2005). Evolutionary relationships of three new species of Enterobacteriaceae living as symbionts of aphids and other insects. Appl Environ Microbiol 71, 3302-3310.

Moran, N. A., McCutcheon, J. P. \& Nakabachi, A. (2008). Genomics and evolution of heritable bacterial symbionts. Annu Rev Genet 42, 165-190.

Oliver, K. M., Russell, J. A., Moran, N. A. \& Hunter, M. S. (2003). Facultative bacterial symbionts in aphids confer resistance to parasitic wasps. Proc Natl Acad Sci U S A 100, 1803-1807.

Pérez-Brocal, V., Gil, R., Ramos, S., Lamelas, A., Postigo, M., Michelena, J. M., Silva, F. J., Moya, A. \& Latorre, A. (2006). A small microbial genome: the end of a long symbiotic relationship? Science 314, 312-313.

Pontes, M. H. \& Dale, C. (2006). Culture and manipulation of insect facultative symbionts. Trends Microbiol 14, 406-412.

Saitou, N. \& Nei, M. (1987). The neighbor-joining method: a new method for reconstructing phylogenetic trees. Mol Biol Evol 4, 406425.

Scarborough, C. L., Ferrari, J. \& Godfray, H. C. J. (2005). Aphid protected from pathogen by endosymbiont. Science 310, 1781.

Tamura, K., Dudley, J., Nei, M. \& Kumar, S. (2007). MEgA4: Molecular evolutionary genetics analysis (MEGA) software version 4.0. Mol Biol Evol 24, 1596-1599.

Tsuchida, T., Koga, R. \& Fukatsu, T. (2004). Host plant specialization governed by facultative symbiont. Science 303, 1989.

Tsuchida, T., Koga, R., Sakurai, M. \& Fukatsu, T. (2006). Facultative bacterial endosymbionts of three aphid species, Aphis craccivora, Megoura crassicauda and Acyrthosiphon pisum, sympatrically found on the same host plants. Appl Entomol Zool (Jpn) 41, 129-137.

Unterman, B. M., Baumann, P. \& McLean, D. L. (1989). Pea aphid symbiont relationships established by analysis of 16S rRNAs. J Bacteriol 171, 2970-2974.

Ventura, M., Elli, M., Reniero, R. \& Zink, R. (2001). Molecular microbial analysis of Bifidobacterium isolates from different environments by the species-specific amplified ribosomal DNA restriction analysis (ARDRA). FEMS Microbiol Ecol 36, 113-121. 
Wayne, L. G., Brenner, D. J., Colwell, R. R., Grimont, P. A. D., Kandler, O., Krichevsky, M. I., Moore, L. H., Moore, W. E. C., Murray, R. G. E. \& other authors (1987). Report of the ad hoc committee on reconciliation of approaches to bacterial systematics. Int J Syst Bacteriol 37, 463464 .
Zhang, C. X., Yang, S. Y., Xu, M. X., Sun, J., Liu, H., Liu, J. R., Liu, H., Kan, F., Sun, J. \& other authors (2009). Serratia nematodiphila sp. nov., associated symbiotically with the entomopathogenic nematode Heterorhabditidoides chongmingensis (Rhabditida: Rhabditidae). Int J Syst Evol Microbiol 59, 1603-1608. 